\title{
Analysis of Roll Stack Deflection in a Hot Strip Mill
}

drsikdar@yahoo.com

R \& D, Tata Steel, India

Shylu John

shylujohn@yahoo.co.in

R \& D, Tata Steel, India

Ashwin Pandit

ashwin.pandit@tatasteel.com

$R$ \& D, Tata Steel, India

Raju Dasu

raju_d_v@yahoo.com

R \& D, Tata Steel, India
Predictive models are required to provide the bending set point for bending for the flatness control devices at rolling stands of finishing mill of Hot Strip Mill (HSM). A simple model for roll stack deflection at the finishing mill has been illustrated where a modified Misaka's equation has been used to obtain mean flow-stress. Investigation has been performed to understand the effect of width of roll on roll stack deflection. The bending on the deflection has been found to have a positive effect to reduce the amount of the stack deflection. The results from the sensitivity analysis of the roll width on roll deflection are also described.

Keywords: hot strip mill (HSM), finishing stands, mean flow stress (MFS), continuously variable crown $(\mathrm{CVC})$, shear stress, bending.

\section{Introduction}

Predictive models are required to provide the bending set point for bending for the flatness control devices at rolling stands of finishing mill of Hot Strip Mill (HSM). A simple model for roll stack deflection at the finishing mill has been illustrated where a modified Misaka's equation has been used to obtain mean flowstress. Investigation has been performed to understand the effect of width of roll on roll stack deflection. The bending on the deflection has been found to have a positive effect to reduce the amount of the stack deflection. The results from the sensitivity analysis of the roll width on roll deflection are also described.

\section{Nomenclature}

$\mathrm{A}=$ Area of cross section of roll, $\mathrm{m}^{2}$

$\mathrm{C}=$ Carbon concentration in $\mathrm{wt} \%$

$D=$ Roll diameter at center, $\mathrm{mm}$

$\mathrm{E}=$ Young's Modulus, $\mathrm{N} / \mathrm{m}^{2}$

$\mathrm{F}=$ Bending force, Newton

$\mathrm{I}=$ Moment of Inertia, $\mathrm{m}^{4}$

$\mathrm{G}=$ Shear modulus, $\mathrm{N} / \mathrm{m}^{2}$

$H=$ Entry thickness, $\mathrm{mm}$

$h=$ Exit thickness, $\mathrm{mm}$

$\mathrm{K}=\mathrm{A}$ constant $(=4 / 3)$

$\mathrm{k}=$ Constant in equation (9)

$\mathrm{L}=$ Contact length between work roll and backup roll, $\mathrm{m}$

$\mathrm{L}^{\prime}=$ Moment arm for bending force, metre.

$\mathrm{M}=$ Bending Moment, N-m.

MFS $=$ Mean flow stress, MPa

$\mathrm{Mn}=$ Manganese concentration in wt \%

$\mathrm{Nb}=$ Niobium concentration in wt $\%$

$\mathrm{P}^{\prime}(\mathrm{x})=$ Force on work roll due to strip, Newton

$\mathrm{q}(\mathrm{x})=$ Force on work roll due to backup roll, Newton

$\mathrm{Q}=$ Geometrical factor

$R=$ Roll radius, $\mathrm{mm}$

$r=$ Reduction at each pass, $\%$

$\mathrm{S}=$ Shearing force, Newton

$\mathrm{S}_{\mathrm{r}-\text { bur }}=$ Shearing force due to back up roll, Newton

$\mathrm{S}_{\mathrm{r}-\mathrm{strip}}=$ Shearing force due to strip, Newton

$\mathrm{T}=$ Temperature, ${ }^{\circ} \mathrm{K}$

Paper accepted March, 2007. Technical Editor: Anselmo E. Diniz.

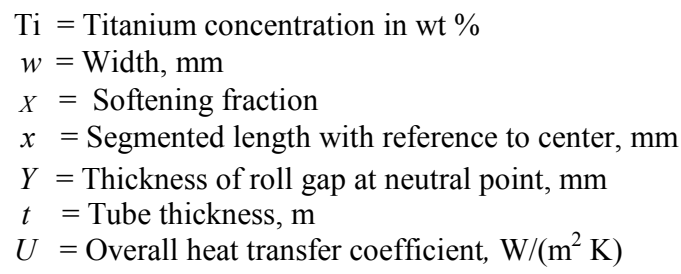

\section{Greek Symbols}

$\Phi=$ Neutral angle, radian

$\bullet$

$\varepsilon=$ Strain rate, $\mathrm{s}^{-1}$

$\varepsilon=$ Strain

$\sigma=$ Stress, $\mathrm{MPa}$

$\delta$ = Deflection, $\mathrm{mm}$

$\begin{array}{ll}\text { Subscripts } \\ b & \text { Bending } \\ d y n & \text { Dynamic recrystallization } \\ M & \text { Reference to Misaka's equation } \\ s S & \text { Steady state } \\ s & \text { Shear }\end{array}$

\section{Scope and Policy}

Today's steel market is guided by the fulfillment of customer demand to meet the stringent requirement of strip quality. Out of various qualities required for the hot rolled product from steel producer, the most important one is the flatness on the strip produced from a Hot Strip Mill (HSM). In a typical HSM, shown in Fig.1, the strip from the roughing mill is passed through the finishing mill via intermediate coilbox. In general, the various contributing factors in the finishing mill of a hot strip mill such as, (i) The thermal crown (ii) The deflection of the work roll and back up roll (iii) The wear in the work roll, leads to the final shape of the strip produced. The final roll gap between the work roll is the cumulative effect of these three factors, which dictates the profile of the strip produced. The roll shifting and bending moment are applied in the rolls of the finishing mills to maintain the required crown and flatness in the strip produced.

In a four-high hot strip mill, the finishing mill of the hot strip mill is equipped with two work-rolls and two back-up rolls and is shown in Fig. 2. During the passage of the strip between the two work rolls, a large amount of roll separating force is developed. This changes the initial set value of roll gap between the work rolls 
(Wilms et al. (1985)). Flatness is dependent on the roll gap or clearance between the working rolls during the process of rolling. Strip profile and flatness can be influenced by the mill features like work roll bending and CVC (Continuous Variable Crown) shifting.

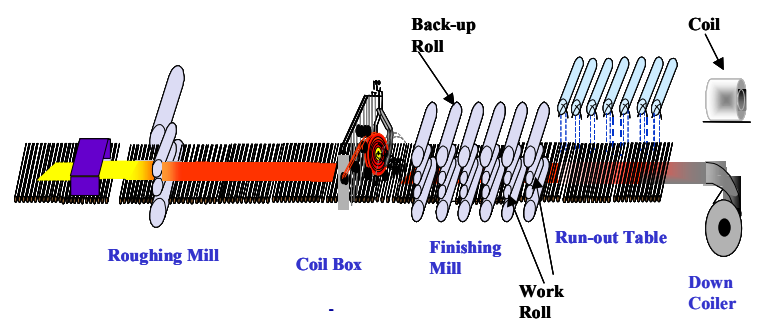

Figure 1. Layout of a typical Hot Strip Mill.

Hence, the knowledge of the contribution of the effect from work roll bending is essential to the people associated with the improvement of profile and flatness. In general, the roll separating force acting between the strip and the work rolls has a parabolic profile. In order to predict flatness and thickness of roll strips, it becomes indispensable to analyze the amount of roll.

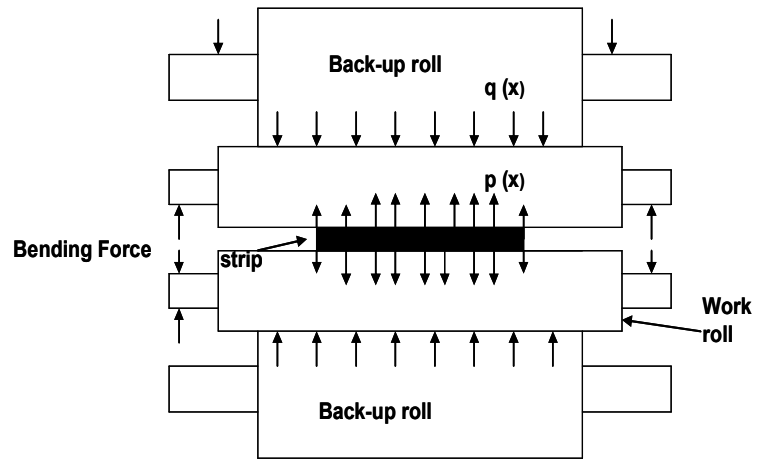

Figure 2. Schematic diagram of forces acting during rolling conditions.

A vast literature with different techniques fills the subject of the roll stack deflection. Out of various simple models, the roll deflection has been obtained from the beam theory in the model of Stone and Gray (1965) where the rolls are presented as a simple beam. Later on this has been adopted by many workers. Another roll deflection model based on the beam theory for the evaluation of the roll deflection in plate rolling was used by Ohe et al. (1994), where they assumed the pressure distribution between the rolled plate and the work roll as well as between the backup roll and the work roll to be a polynomial of fourth degree. Many other workers have also worked to determine the roll stack deflection for reducing the profile and flatness error. Steel producers can achieve improvement in the productivity and quality by improving the profile and flatness and for this reason; it is of utmost importance to analyze the effect of various parameters in improving the quality such as work roll deflection, backup roll deflection.

This article describes a mathematical model based on simple deflection equations for each stand of six finishing mills in a hot strip mill and this describes the effect for a whole schedule of rolling. This simple model is an easy resort to estimate the roll deflection instead of several complex models described in the literature. The purpose of this work is to find out the effect of different parameters on roll deflection. For six stands, the overall roll deflection values are evaluated. The effects of the size of the strip width and roll bending values have also been studied.

\section{Strip Profile and Shape}

Profile and flatness in the rolling of strip are related to each other in rolling operation. Achieving the flatness requirements in rolling thinner gauge sheets has always been greater challenge as we encounter fewer flatness problems in rolling of thicker gauge sheets. Crown is the difference in thickness between the centre and at a point $40 \mathrm{~mm}$ from the edge of the strip (taken average of both sides). Flatness or Shape is defined by the degree to which a flat rolled product is planar, when not subjected to external constraining forces.

The deflection of the work rolls results in a widthwise distribution of strip thickness in the form of a convex crown, in which the thickness is greater at the center of the width and smaller at the edges. This widthwise difference in thickness is known as the strip crown. To reduce the convex shape, in general, a bending force is applied in the opposite direction. The work roll bending forces are applied to the work roll chocks that are located at the roll ends. When roll bending forces are applied in the direction of opening the roll gap, this is known as positive or crown-in roll bending. Inversely, when the roll bending forces are applied in the direction of closing the roll gap, this type of bending is termed negative or crown-out roll bending. Positive roll bending causes the strip profile to be concave whereas negative roll bending causes the strip profile to be convex.

\section{Mill Configuration}

In the hot strip mill under study, the slabs from the slab caster are rolled into strips by reducing their thickness from $210 \mathrm{~mm}$ to a value ranging from $1.6 \mathrm{~mm}$ to $12 \mathrm{~mm}$, with the width of the strip ranging from 860 to $1540 \mathrm{~mm}$. The slabs are heated and soaked in a Walking Beam type-reheating furnace up to a temperature of almost $1250^{\circ} \mathrm{C}$. At four-high reversing roughing stand, the heated slabs are reduced to a thickness of $30 \mathrm{~mm}$ with seven passes. Finally, the required thickness is achieved in a four-high six-stand tandem finishing mill $\left(F_{1}\right.$ to $\left.F_{6}\right)$ at a finish rolling temperature of 870 $900^{\circ} \mathrm{C}$, depending on the grades. Centrifugally cast high chrome rolls are used for the purpose of work rolls of six finishing mill having a barrel length of $2000 \mathrm{~mm}$ and a diameter ranging from 660 $\mathrm{mm}$ to $710 \mathrm{~mm}$. With the objective to achieve required metallurgical properties at different coiling temperature, the strip from finishing stands are cooled in the Run Out Table (ROT), where it is water cooled and coiled finally in the down coiler.

A large number of slabs are rolled in a schedule of rolling by the work rolls of finishing stands until work rolls are replaced at the end of the schedule. A whole schedule contains the mixture of the slabs of different grades of steels of different width and different target thickness in the hot strip mill. In general the number of strips produced from a schedule varies from 45-60 depending on the requirement and availability of slabs. A coffin schedule is followed in hot strip rolling to arrange the width of the slabs to be rolled. In this arrangement, slabs with lower width are placed at the beginning of the rolling and the width of slabs are gradually increased up to a maximum value and after that the width is reduced to close the starting values of slab width. In nutshell, the slabs arranged in this way looks like the shape of a coffin.

\section{Shapes of work roll}

As the length of the work roll and back up roll are equal, the effect of roll bending is not prominent to reduce the crown. To obviate this problem, the use of tapered crown work rolls in a Japanese steel plant, as mentioned in the paper by Kitahama et al. (1987), was introduced, where shifting of the work roll was made to compensate for crown developed. Later on many plants use CVC 
(Continuously Variable Crown) developed by SMS (SchloemannSiemag ) where the shifting the work rolls in the opposite directions reduces the roll separating force. The finishing mill is equipped with Continuous Variable Crown (CVC) technology with a maximum biaxial shifting of $\pm 150 \mathrm{~mm}$ for stands $F_{2}$ to $F_{6}$ and roll bending $\left(F_{1}\right.$ to $F_{6}$ ) for shape control. The work rolls in stand 1 are cylindrical. In CVC system, two axially rolls have a shape of "S" and deviate from a cylindrical shape by a dimension of range of microns. The opposite shifting enables the operator to achieve symmetrical thickness profile. The movement of the both rolls in pair in the opposite direction acts like the conventional cylindrical rolls to produce a crown. A smaller or bigger size of crown can be achieved by the mode of the direction of the shifting. The work-roll shifting type aims to make the strip thickness uniform and improve the flatness over a wide range of strip widths by shifting CVC rolls.

A linear relationship exists between the effective roll crown and the CVC shifting. The range of crown adjustment depends on the shifting distance and the difference between the maximum and minimum diameter of the S-shaped roll.

\section{Mathematical Model}

In this section, we describe the method of development of the deflection model, based on short beam deflection theory, to predict the deflection of the work roll at different positions along the length of the roll at the finishing stands of the Hot Strip Mill. This model takes into account the following assumptions:

(i) The work roll is considered to be cylindrical instead of CVC roll.

(ii) No work roll shifting is considered.

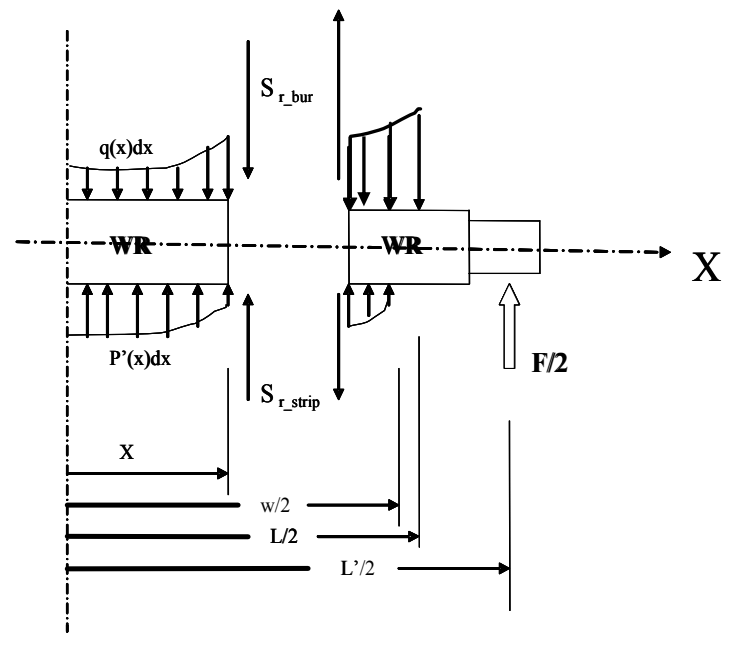

Figure 3. Free body diagram of work roll.

To develop a simple deflection model the deflection of the work-roll and back-up roll are considered. For the calculation of the roll deflection, the theory uses the roll as simply supported overhanging beam. The backup roll is considered as a simply supported beam. The elastic roll deformation is determined by superimposition of deflection due to bending $\left(\delta_{b}\right)$ and deflection due to shear $\left(\delta_{S}\right)$ on the roll.

Figure 3 shows the free-body diagram depicting different forces acting on the work roll of a finishing stand. From the free-body diagram (Fig. 3) of the work-roll:

\section{Deflection by Bending,}

E.I. $\frac{d^{2} \delta_{b}}{d x^{2}}=M$

Deflection by shear stress,

$$
\frac{G A}{K} \cdot \frac{d \delta_{s}}{d x}=S
$$

where, E: Young's Modulus, I: Moment of inertia, S: Shearing force, A: Area of cross section of roll, M: bending Moment, G: Modulus of rigidity, K: 4/3. For the determination of bending moment, the roll force is required. In this model the roll force is calculated first. The flow diagram of roll stack deflection model is shown in Fig. 4.

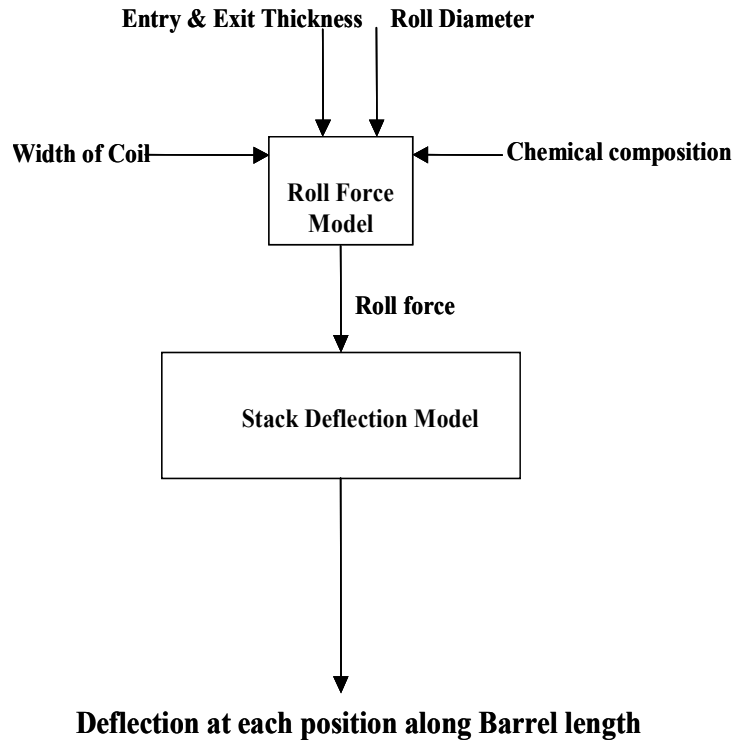

Figure 4. Flow diagram for the development of stack deflection model for a number of coils in a schedule.

The deflection of backup roll axis is calculated in a similar manner. To determine the work roll deflection along with the deflection of backup roll, the roll force between work roll and back up roll is necessary. The roll force is determined with roll force model, described in the following sections.

This roll force is used in determining the bending and the shear force in Eq.(1) \& Eq.(2). The roll diameter and related thickness of the strip for the chosen schedule of rolling are given in the Table 1. The area of cross section of work roll can be determined from the data of the table.

Table 1. Dimension of work roll and thickness of strip at finishing stands of the selected schedule for analysis.

\begin{tabular}{|c|c|c|}
\hline $\begin{array}{l}\text { Finishing stand } \\
\text { No. }\end{array}$ & $\begin{array}{l}\text { Roll diameter } \\
(\mathrm{mm})\end{array}$ & $\begin{array}{l}\text { Strip thickness at the } \\
\text { exit of individual stand } \\
(\mathrm{mm})\end{array}$ \\
\hline 1 & 719 & 20.61 \\
\hline 2 & 706 & 14.49 \\
\hline 3 & 672 & 10.46 \\
\hline 4 & 689 & 8.08 \\
\hline 5 & 675 & 6.59 \\
\hline 6 & 712 & 5.55 \\
\hline
\end{tabular}




\section{Roll Force Model}

Specific force between the rolls (inter-roll specific force) has been calculated from the roll force model. This model uses the mean flow stress (MFS) of the material to calculate the rolling load. Several phenomena such as recrystallization, strain accumulation and phase transformation can be evaluated with the MFS behavior during rolling. The roll force for each stand was calculated using the Sims (1954) approach. Essentially, this calculation requires the strip thickness, width and MFS of the material for each pass. The Sims equation used for the calculation is as follows:

$P=\left(\frac{2}{\sqrt{3}}\right) \cdot M F S \cdot w \cdot(R \cdot(H-h))^{\frac{1}{2}} \cdot Q$

where, MFS $=$ Mean flow stress, $\mathrm{w}=$ width, $\mathrm{R}=$ Work roll radius, $\mathrm{H}=$ Entry thickness, $\mathrm{h}=$ Exit thickness and, $\mathrm{Q}=$ Geometric constant.

$r=\frac{H-h}{H}$

$Q=\left(\frac{1}{2}\right)\left(\frac{1-r}{r}\right)^{\frac{1}{2}}\left(\tan ^{-1} \frac{r}{r-1}\right)^{\frac{1}{2}}-\left(\frac{R}{h}\right)^{\frac{1}{2}} \ln \left(\left(\frac{Y}{h}\right)^{2}(1-r)\right)-\frac{\pi}{4}$

$Y=2 R(1-\cos \Phi)+h$

The flow stress is governed by the repeated recrystallization which can be either static or dynamic. It depends on the interpass time, strain, strain rate and temperature. Misaka's equation from Misaka and Yoshimoto (1967) has been used to specify the MFS for $\mathrm{C}-\mathrm{Mn}$ steels during hot strip rolling and the equation is given by:

$$
\begin{aligned}
& M F S_{M}=9.81 \exp \left(0.126-1.75[C]-0.594[C]^{2}+\right) \varepsilon^{0.21} \dot{\varepsilon}^{0.13} \\
& +9.81 \exp \left(\frac{2851+2968[C]-1120[C]^{2}}{T}\right) \varepsilon^{0.21} \dot{\varepsilon}^{0.13}
\end{aligned}
$$

where, $\mathrm{MFS}_{\mathrm{M}}$ is the modified Misaka's equation for MFS in MPa and $[\mathrm{C}]$ is the carbon concentration in weight $\%, \mathrm{~T}=$ Temperature, in ${ }^{\circ} \mathrm{K}$ Later on, Siciliano et al. (1996) modified equation (7) to incorporate the effect of different alloying elements such as $\mathrm{Mn}, \mathrm{Nb}$, Ti etc. and the softening due to dynamic recrystallization, if any. The modified equation is restructured as follows:

$$
\begin{aligned}
& M F S^{*}=\operatorname{MFS}_{M}(0.768+0.51[N b]+0.137[\mathrm{Mn}]+4.217[\mathrm{Ti}]) \\
& M F S=\operatorname{MFS}^{*}\left(1-X_{d y n}\right)+k \sigma_{S S} X_{d y n}
\end{aligned}
$$

here a constant factor of $\mathrm{k}=1.14$ is introduced to convert the stress to mean flow stress. The MFS during rolling at each stand, as calculated by Eq. (9), was used in Eq. (3) for the calculation of roll force.

The mean flow stress, determined from Eq.(7) is similar to the nature of the graphs of Pankaj et al. (2004) for plain C-Mn grade and microalloyed grade steel:

$$
M F S=f(1 / T)
$$

where $\mathrm{T}=$ Temperature

In case of $\mathrm{Nb}$ microalloyed steels, the presence of $\mathrm{Nb}$ in solid solution causes the retardation of static recrystallisation (SRX). During finishing stages of strip rolling, strain accumulation occurs due to short interpass time, and dynamic recrystallisation (DRX) followed by metadynamic recrystallisation (MDRX) occurs. The evolution of MFS as a function of inverse absolute temperature is

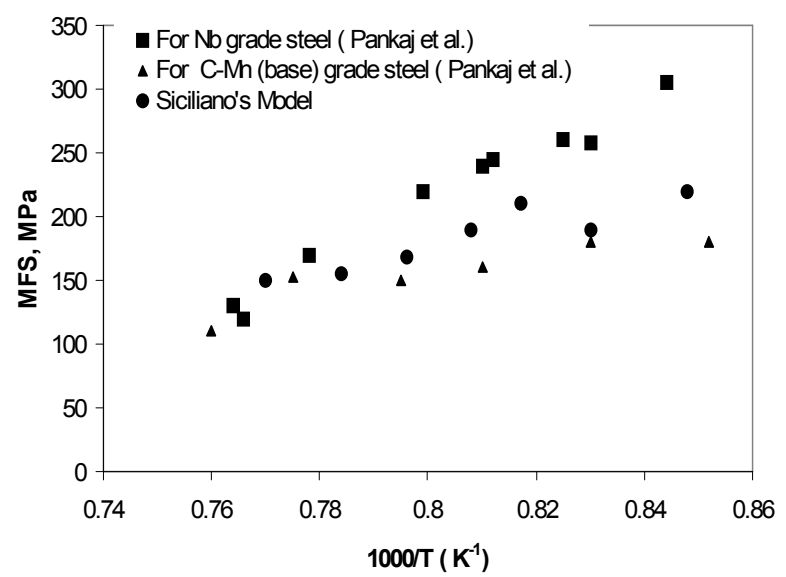

Figure 5. Comparison of MFS as a function of the inverse absolute temperature.

depicted in Fig. 5 by comparison of the data from the work of Sicliano (2004).

\section{Validation}

The comparison between the predicted and the measured (actual) roll force for a selected schedule at the finishing stand no. 2 of the hot strip mill is shown in Fig. 6. The average of measured

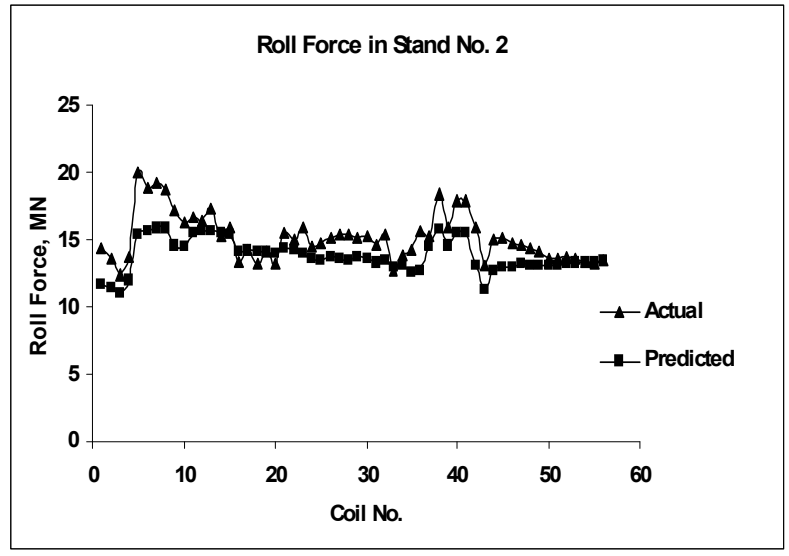

Figure 6. A comparison of predicted vs. actual roll force for stand no. 2 in a complete schedule of rolling.

force (in MN, MegaNewton) for each coil is taken from the hot strip mill (HSM). For the whole schedule, average values of actual force for each coil are captured by level-II automation in HSM with the help of load cell located in the finishing mill housing. The predicted and the actual roll forces are found to be in good agreement. The deviations of the average of actual roll force for $80 \%$ of the coils are found to be with in $7-8 \%$. In some cases, the prediction matches with the actual value of the average roll force. Similar results are found to be true for all the other stands. 


\section{Results}

The results encompass the analysis of the model simulation with the data of strip rolled and the work rolls of the finishing stands of a complete schedule. The roll diameter, entry and exit thickness for each stand as well as chemical composition and width for each coil of the schedule have been used as input for the roll deflection model.

Figure 7 displays the variation of deflection with the width for different finishing stands simulated by the model. For any stand of the finishing mill, the amount of deflection increases with the increase of the width of the work roll and after a particular value of width the deflection again starts drooping down. This result implies that the maximum deflection can be obtained for a particular width of the strip, which is about $55-60 \%$ of work roll length. A similar observation has been made in the reference literature by Ginzburg (1995) also. It is noticed from the simulation study that the strip width has a significant effect on the roll deflection. The strip transmits the rolling load between the work rolls, which are generally greater in length than the strip width. The work roll deflection increases with an increase in strip width, whereas for wider widths deflection decreases with an increase in strip width, reaching its maximum value of $55-60 \%$ of the barrel length. This

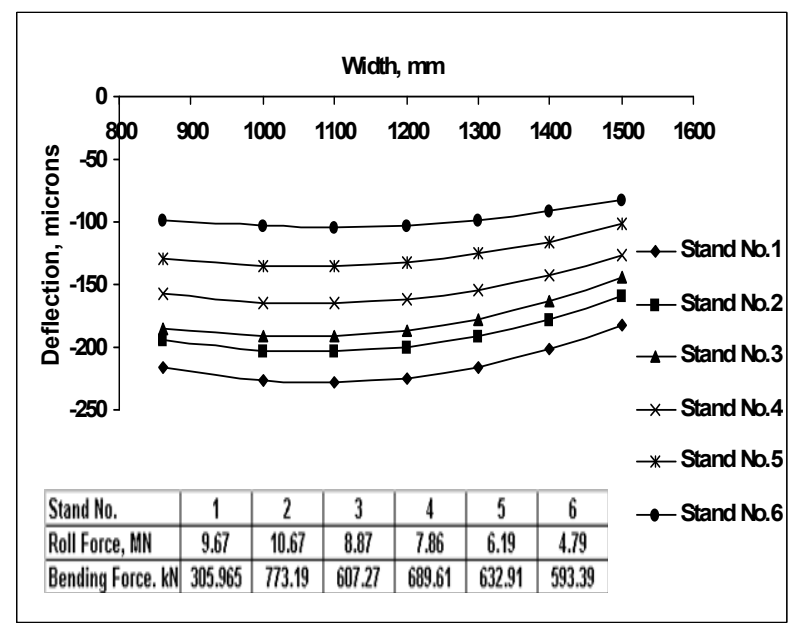

Figure 7. Effect of strip width on roll deflection at different stands (\#).

trend is basically due to the effect of strip width on the roll force i.e. with the increase in width, the roll force increases up to a value of width and then decreases.

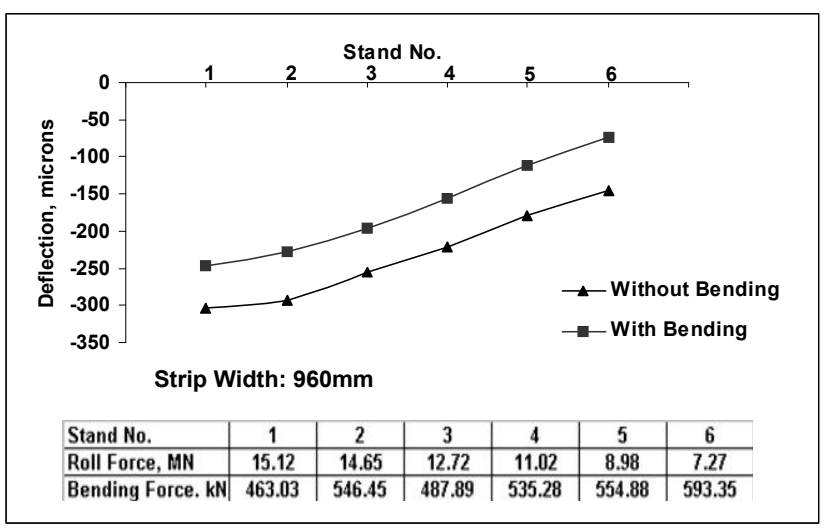

Figure 8. Comparison of bending and no bending on roll deflection (Entry Thickness: $29.27 \mathrm{~mm}$, Exit thickness: $2.02 \mathrm{~mm}$ ).
The effect of work roll bending at different stands of the finishing mill is illustrated in Fig. 8. The effect of bending and without bending creates two parallel curves. The relative profile at different stands with bending remains constant, as can be seen by the curves, which are parallel. Thus, the roll bending force is designed in such a way so as to maintain a uniform relative profile at different stands to avoid flatness error. Here, the roll force is decreasing with subsequent stands, thereby reducing the deflection. The difference of the deflection value with and without bending for the particular process parameter lies between 50-60 microns. The table in the inset shows the parameters of roll force and bending force considered for the analysis. The inset in the Fig. 7 also shows the roll force and bending force values considered for the analysis.

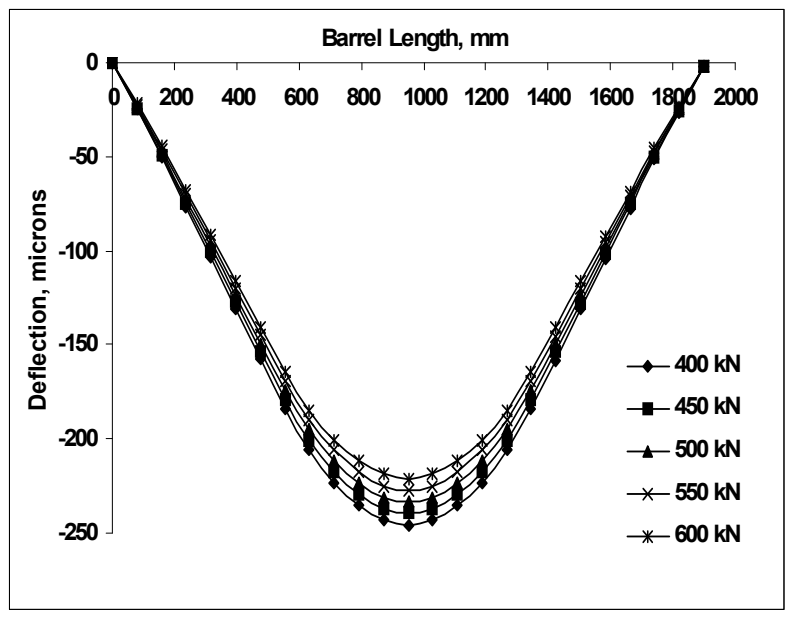

Figure 9. Effect of roll bending on roll deflection of stand 1 (Roll Force: 14.07 MN, Strip Width: $900 \mathrm{~mm}$, Entry Thickness: $29.27 \mathrm{~mm}$, Exit thickness: $2.02 \mathrm{~mm}$ ).

Figure 9 portrays the result of the variation in deflection along the barrel length of stand 1 for increasing bending forces, keeping the roll force and strip width constant. Significant point to be observed is the decreasing trend of the amount of deflection with the increase in bending force up to a particular barrel ( roll) length. Thus roll bending is a controllable parameter to modify the roll gap and hence the crown and flatness of the strip rolled in the finishing mill of the hot strip mill.

\section{Conclusions}

Roll stack deflection is an important issue in the determination of profile and flatness of a strip rolled in hot strip mill. A simple roll deflection model has been developed to predict the deflection of the finishing stands of a hot strip mill. The roll deflection model indicates the effect of width for deflection as well as the effect of bending. The effect of work roll bending and the roll width has been studied by this model. It has been observed that the increase of width of work roll leads to the increase of roll deflection upto a certain value following which it again decreases with the increase of width of work roll.

The amount of deflection of rolls at different stands can be changed by applying roll bending. The roll stack deflection calculated in the above method can be used as an input for determining the roll gap along the barrel length for flatness. 


\section{Acknowledgement}

The authors acknowledge the kind permission of the management of Tata Steel, India for the publication of this paper.

\section{References}

Bald, W., Beiseman, G.., Feldmann, H. and Schultes, T., 1987, "Continuous Variable Crown (CVC) Rolling", AISE Year Book, pp. 127136.

Ginzburg, V.B., 1995, "Profile and Flatness of Flat Rolled Products", Rolling Mill Technology Series, Part II, International Rolling Mill Consultants, Inc., Pittsburgh, PA, USA, pp.4-32.

Kitahama, M., Yarita, I., Abe, H. and Awazuhara, H., 1987, "Profile Control of hot rolled strip by work roll shifting (K-WRS) mill”, AISE Year Book, pp. 474-483.

Misaka, Y. \& Yoshimoto, T., 1967, J. Jpn. Soc. Technol. Plast., Vol. 8, pp.414.

Ohe, K., Morimoto, Y., Kajiura, S., Fujino, T. , Simada, S., Anarku, K. and Mizuta, A., 1994, "Development of Shape Control in Plate Rolling",
METEC Congress 94 Proceedings, Vol. 2, $6^{\text {th }}$ International Rolling Conference, VDEh, Dusseldorf, Germany, pp. 78-85.

Pankaj, Venugopalan, T., Mohapatra, S., Ravi, R. S. and Sadhu, M.C., 2004, "New Product Development using the Hot Strip Mill as an Experimental Tool", Tata Search, Vol. 2, pp. 280-283.

Pospiech, J., 2005, "Calculation method for deformation of stands and rolls to obtain products with small dimension of tolerances", Journal of Materials Processing Technology, Vol. 166, pp. 417-422.

Siciliano Jr, F., Minami, K., Maccagno , T.M. and Jonas, J.J., 1996, "Mathematical Modeling of the Mean Flow Stress, Fractional Softening and Grain Size during the Hot Strip Rolling of C-Mn Steels", ISIJ International, Vol. 36, pp.1500-1506.

Siciliano, F., 2004, "Modeling the Mean Flow Stress and Grain Sizes During the Hot Rolling of Niobium Microalloyed Steels using Industrial Data", SimPro'04, International Conference on Thermo-mechanical Simulations and Processing of Steels, Ranchi, Jharkhand, India, pp 217-235.

Sims, R.B., 1954, "The calculation of roll force and torque in hot rolling mills", Proc. Inst. Mech. Eng., Vol. 168, pp.191-200.

Stone, M.D. \& Gray, R., 1965, "Theory and Practical Aspects in Crown Control", Iron and Steel Engineer Year Book, pp. 657-674.

Wilms,W., Vogtmann, L., Klockner, J., Beisemann, G. and Rohde, W., 1985, "Profile and Flatness Control in Hot Strip Mills", Metallurgical Plant and Technology, Vol. 8, pp. 74-90. 